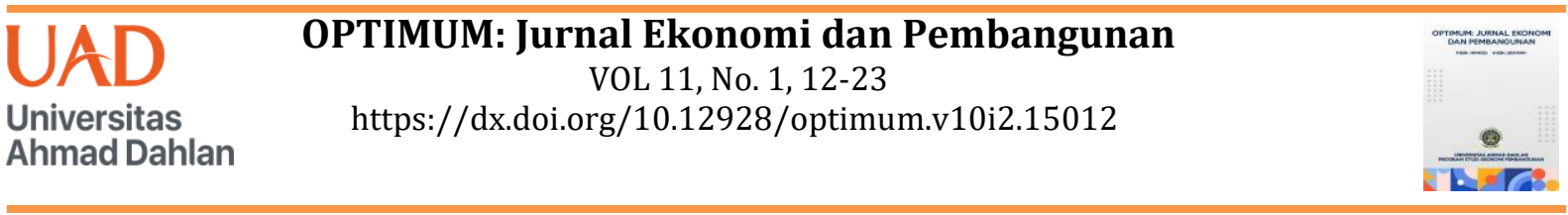

\title{
Determinants of Credit in Indonesia's Agricultural Sub-Sector: Panel Data Analysis
}

\author{
Dini Yuniarti1,a*; Arif Sapto Yuniarto²,a \\ 1 dini.yuniarti@uad.ac.id; ${ }^{2}$ arif.yuniarto@act.uad.ac.id \\ a Faculty of Economics and Business, Ahmad Dahlan University \\ * corresponding author
}

\section{ARTICLE INFO}

\section{Article history}

Received 2021-01-26

Revised 2021-03-09

Accepted 2021-03-10

Keywords

Determinant

Farmer

Credit

Financial

Literation

\section{ABSTRACT}

Credit has a role in agricultural development and the income of small farmers which will reduce poverty levels. However, the portion of credit in the agricultural sector is still relatively small. This study aims to examine determinants of credit in the agricultural sub-sector. The factors include credit rating, credit interest rates, Gross Domestic Product and the number of farmers in the agricultural sub-sector. The data used are secondary data, a combination of cross-sectional data including the agricultural sub-sector, namely food crops, horticultural crops, plantations and livestock and seres times including 2011-2019. The analysis tool used is the regression data panel. The study results show that the number of creditors in the agricultural sector is positive and significant by the number of farmers and Gross Domestic Product, while interest does not affect the credit rating of the agricultural sub-sector. Policies that can be taken are to increase the Gross Domestic Product of the agricultural sector to increase the capacity of farmers. In addition, to increase farmers' access to financial institutions, financial education is needed, so that it will increase financial literacy.

This is an open access article under the CC-BY-SA license.

\section{Introduction}

Pada The Financial Services Authority (2016) states that financial literacy and inclusion are global issues considering their impact on the economy, and the fact that the level of financial literacy and inclusion is still low in the majority of countries in the world. Various state authorities and international institutions such as the World Bank, OECD, and the IMF have made it an issue. The respective authorities and institutions with an interest in policies that support increased literacy and financial inclusion must immediately be taken in order to increase public financial literacy and inclusion since financial literacy has an impact on the economy. An increase in the level of public financial literacy will encourage people to be able to determine and utilize financial service products so that it will encourage community 
welfare (Hogarth et al., 2007). In addition, according to Park \& Mercado (2015) an increase in the level of financial literacy will have an impact on an increase in the level of financial inclusion. This will reduce inequality and the rigidity of low income trap. The same thing was stated by Ummah et al (2015). This condition will improve the welfare of the community and in turn will reduce the level of poverty. The same thing was stated by (Park \& Mercado, 2015). For the case in Indonesia, the study of Ummah et al (2015) shows that financial inclusion has a direct relationship with income distribution in Indonesia. The income distribution in an area affects the level of financial inclusion in that area, but not vice versa.

Nationally, financial literacy and inclusion have become significant issues because they relate to many aspects, one of which is poverty reduction. This is demonstrated by the collaboration between Bank Indonesia and the Secretariat of the Vice President - the National Team for the Acceleration of Poverty Reduction (TNP2K) and the Fiscal Policy Agency - the Ministry of Finance in the form of a National Strategy for Financial Inclusion. This program was formed to support the government in reducing poverty and developing an inclusive and sustainable economy (Ummah et al., 2015)

One group that is pretty much vulnerable to poverty is the farmer household. The data from Central Bureau of Statistics (BPS) show that the percentage of poor people in March 2019 was 9.41 percent or 25.14 million people. $15.15 \%$ of the total population lives in rural areas where many farmers inhabit these places. Therefore, it can be said that farmers have a higher poverty rate than other groups. Even though it has decreased compared to the previous period, it is still above the poverty target set in the 2015-2019 RJPMN, at 7.0 - 8.0\% at the end of 2019.

According to Poliquit (2006) credit has a role in agricultural development, and it is believed that the expansion of the credit program will provide benefits for agricultural production and smallholder income, which then able to reduce poverty levels and also diversifying livelihoods and improving business skills. The role of bank credit is very strategic in the development of the agricultural sector, but unfortunately, the amount of credit in the agricultural sector has been too low to this date (Darmawanto, 2008). According to Cahyono \& Mardianto (2017), one of the problems faced by farmers is their lack of access to formal financial institutions. In fact, farmers need additional capital to increase their production. Sharia banking is a financial institution that is close to the real sector, especially agriculture. However, financing for this sector is still very small. The main reason for this is that the agricultural sector has a very high risk. This is a challenge for the banking and financial sectors, both conventional and sharia, to expand market access. 
Furthermore, access to capital sources is still a major problem faced by farmers in Indonesia, who mostly have narrow land and are considered not bankable by credit-giving financial institutions (Hardana et al., 2019).

Table 1 shows the position of credit in the economic sector. The agricultural sector has a relatively small proportion, with an average of 9.7\% during 2017-2019. Even though it is not the smallest proportion, if compared to the number of workers who depend on the agricultural sector, the proportion is very small. Considering that the Central Bureau of Statistics report in August 2020 shows that the population working in the agricultural sector is 29.76 percent of the total workers in Indonesia, which is around 38.23 million people. This shows that there are still fewer players in the agricultural sector who access credit to financial institutions compared to other economic sectors. According to Ashari (2009a), weak capitalisation is still one of the main problems faced by agricultural businessman. For this reason, it is necessary to study the factors that affect credit. The results of this study are expected to provide policy recommendations for increasing credit in the agricultural sector.

Table 1. Credit by Economic Sector 2017-2019 (Billion Rp)

\begin{tabular}{|c|c|c|c|c|c|c|c|}
\hline No & Sector & 2017 & $(\%)$ & 2018 & $(\%)$ & 2019 & (\%) \\
\hline 1 & $\begin{array}{l}\text { Agriculture, Animal } \\
\text { Husbandry, Forestry \& } \\
\text { Fisheries }\end{array}$ & 326.057 & 9,8 & 365.044 & 9,8 & 376.421 & 9,7 \\
\hline 2 & Mining and excavation & 03.723 & 3,1 & 127.044 & 3,4 & 127.384 & 3,3 \\
\hline 3 & Processing industry & 02.701 & 24,1 & 874.442 & 23,4 & 880.095 & 22,8 \\
\hline 4 & $\begin{array}{l}\text { Electricity, Gas and } \\
\text { Clean Water }\end{array}$ & 44.964 & 4,4 & 168.359 & 4,5 & 194.386 & 5,0 \\
\hline 5 & Construction & 57.215 & 7,7 & 314.966 & 8,4 & 359.288 & 9,3 \\
\hline 6 & $\begin{array}{l}\text { Trade, Hotel and } \\
\text { Restaurant }\end{array}$ & 73.134 & 29,2 & 1.064 .488 & 28,5 & 1.078 .921 & 27,9 \\
\hline 7 & $\begin{array}{l}\text { Transportation and } \\
\text { Communications }\end{array}$ & 80.758 & 5,4 & 214.635 & 5,7 & 223.244 & 5,8 \\
\hline 8 & $\begin{array}{l}\text { Finance, Real Estate } \\
\text { and Corporate Services }\end{array}$ & 32.602 & 13,0 & 487.762 & 13,0 & 491.493 & 12,7 \\
\hline 9 & Services & 10.342 & 3,3 & 124.711 & 3,3 & 130.406 & 3,4 \\
\hline \multicolumn{2}{|c|}{ Tot } & 3.331 .495 & 100 & 3.741 .452 & 100 & 3.861 .636 & 100 \\
\hline
\end{tabular}

Source: The Ministry of Agriculture (2019)

The factors that affect credit are generally divided into external factors and internal factors (Rai \& Purnawati, 2017). Third party funds (DPK), Capital Adequacy Ratio (CAR), and Non-Performing Loans (NPL) are internal factors, while Bank Indonesia Certificates (SBI) and Interest Rates are categorized external factors. This study intends to examine external factors on the amount of credit. Many studies have examined the external factors 
that affect credit. External factors include, among others, interest rates (Kalesar et al., 2016; Purba et al., 2016; Asrori, 2012), inflation (Ismail, 2018; Kalesar et al., 2016; Maiti et al., 2020; Mewoh et al. ., 2017), Gross Domestic Product (Kalesar et al., 2016).

Studies that specifically examine credit in the agricultural sector have also been carried out, where the dominant factors are interest rates (Maulana \& Iskandar, 2018; Rompas, 2018), income (Aggarwal et al., 2014; Hardana et al., 2019), population (Jannah, 2018), land area (Hardana et al., 2019), and education (Hardana et al., 2019). Interest rate has a negative effect on credit because it must be paid by borrowers. The higher the interest rate, the higher the amount to be paid. The burden on the community in repaying their credit loans is getting heavier, and will reduce the interest of the community to apply for credit which results in a decrease in the credit channeled (Irfan et al., 2014).

National income in the form of Gross Domestic Product has a positive effect on the amount of credit. This is related to the criteria for providing credit, that are the capacity and the conditions of economy. According to Astuty (2015), capacity can be determined through production figures. In addition, the condition of economy observes general economic conditions as well as conditions in the business sector of the party applying for credit. The better the Gross Domestic Product value of the agricultural sector is, the better the production figures of the agricultural sub-sector and the economic condition sector are, which leads to an increase of credit applications. Moreover, with the increase in income, the realization of the provision of credit proposed by the public will increase as a result of banking confidence in the ability to pay debtors (Irfan et al., 2014). As for the number of farmers, it has an influence on the amount of credit. The increase of the population will increase the amount of capital needed so that it will increase credit applications in the agricultural sector.

This study examines the determinants of credit in the agricultural sector. The factors that are included are credit interest rates, Gross Domestic Product / GDP of the agricultural sub-sector, and the number of farmers. Other factors such as land area and farmer education are not included in the analysis, due to limited data.

So far, studies on the position of credit in the agricultural sub-sector have not been carried out. For this reason, this study intends to examine the determinants of agricultural credit in the agricultural sub-sector. The study of the agricultural sub-sector will provide more detailed information on credit in the agricultural sector. This study divides the agricultural sector into several sub-sectors such as Agriculture, Animal Husbandry, and Forestry and Fisheries, but due to limited data for all variables, the sub-sector analyzed is 
only the Agriculture and Animal Husbandry including food crops, horticultural crops, plantations and livestock.

\section{Method}

The analysis of the credit interest rates effect, Gross Domestic Product and the number of farmers according to the agricultural sub-sector, was carried out using regression analysis tools. The type of data used is quantitative data, while the data source comes from secondary data. The time dimension is a combination of secondary data cross section and time series. The cross section data cover four agricultural sub-sectors consisting of food crops, horticultural crops, plantations and livestock. The time series data cover the period of 2011-2019. The dependent variable is the credit position of the agricultural sub-sector in Indonesia. The independent variables are the average credit interest rate according to the agricultural sub-sector, the number of farmers in the agricultural sub-sector, and the GDP of the agricultural sub-sector at constant prices. Credit position data and credit interest rates are derived from the Ministry of Agriculture's Macro Indicator Statistics for the Agricultural Sector. The data on the number of farmers comes from the Agriculture Sector Employment Statistics of the Ministry of Agriculture. Agricultural sub-sector Gross Domestic Product data comes from the Central Statistics Agency report.

This study uses panel data analysis tools, equation 1 shows the relationship between the dependent variable and the independent variable.

$K=b_{0}+b_{1} S B i t+b_{2} J P i t+b_{3} P i t+\varepsilon$

Where the definitions of the equation are:

$\mathrm{K}$ : credit position in the agricultural sub-sector (billion rupiah)

SB : average interest rates by agricultural subsector (percent)

JP : number of farmers in the agricultural sub-sector (soul)

P : Gross Domestic Product from agriculture sector (billion rupiah)

i : agriculture sub-sector (food crops, horticultural crops, plantations, and livestock)

t : 2011-2019

$b_{0}, b_{1}, b_{2}, b_{3}$ : independent variable regression coefficient.

Before performing panel data analysis, the right specification will be selected among a common effect model, a fixed effect model, and a random effect model. After determining the appropriate model specification, then hypothesis testing will be carried out through statistical tests known as partial and simultaneous test, which then explain the coefficient of $\mathrm{R}^{2}$ determination. 


\section{Results}

Table 2 presents all the models derived from the estimation of panel data regression using common Effect Model (CEM), Fixed Effect Model (FEM), and Random Effect Model (REM). Before testing the hypothesis, it is necessary to first test the appropriate mode specification. To test both Common Effect Model and Fixed Effect Model, the Chow test is used. Based on the results of the data processing, the value is 18.44, significant at $\alpha 5 \%$, which shows that the appropriate model is the fixed effect model (FEM). The next step is to determine whether FEM or REM is the more appropriate model. The chi square value shows 26.107, significant at $\alpha 5 \%$, meaning that the FEM model is more appropriate to be used. Based on this test, it can be concluded that the model that is the most appropriate for the estimation is the fixed effect model (FEM).

After determining the most appropriate model, the Fixed Effect Model or FEM, Testing will be carried out using apriori economic test, partial and simultaneous statistical tests, and explaining the coefficient of determination. Based on the estimation results, the variable number of farmers and GDP passed apriori test where the estimation results were in accordance with the hypothesis. On the other hand, the estimated interest rate variable was not in accordance with the hypothesis with the positive coefficient value, while the hypothesis was negative. Therefore, it did not pass the apriori economic test. The partial testing, the $t$ test, shows the variable number of farmers in the agricultural sub-sector and GDP of the agricultural sub-sector has a positive effect on the credit position of the agricultural sub-sector in Indonesia during 2011-2019. Differently for the interest rate variable, because it does not pass apriori economic test, it does not have a negative effect on the credit position of the agricultural sub-sector. To test the hypothesis simultaneously, it shows the value of $\mathrm{F}$ count 30,598 , significant at $\alpha 5 \%$. The determination coefficient, the adjusted R2 shows a value of 0.835 , meaning that $83.5 \%$ of the variation in the credit position of the agricultural sub-sector can be explained by variables in the model, while the remaining $16.5 \%$ is explained by variables outside the model. The constant coefficient per sub-sector shows that there are differences, even though they have the same slope. The horticultural sub-sector is the sub-sector that has the highest value, then the livestock, plantation sub-sector and finally food crops. 
Table 2. Data Panel Analysis Result

\begin{tabular}{lccc}
\hline \multirow{2}{*}{ Variables } & \multicolumn{3}{c}{ Estimation Model } \\
\cline { 2 - 4 } & Common Effect & Fixed Effect & Random Effect \\
\hline Constant & $-166794.3^{*}$ & $-265045.6^{*}$ & $-223069.9^{*}$ \\
Credit interest rate & $5068.9^{*}$ & $2814.0^{*}$ & $7425.1^{* *}$ \\
Number of farmers & $-0.0119^{* *}$ & $0.005^{* *}$ & $-0.017^{*}$ \\
Agricultural $\quad$ sector & $1.16981^{*}$ & $1.079^{*}$ & $1.516^{*}$ \\
GDP & & & \\
C_Food Crops & - & -131286.6 & $-6.53 \mathrm{E}-10$ \\
C_Horticulture & - & 80154.51 & $-6.51 \mathrm{E}-11$ \\
C_Plantation & - & -23481.46 & $4.00 \mathrm{E}-10$ \\
C_Animal Husbandry & - & 74613.54 & $3.19 \mathrm{E}-10$ \\
\hline R $^{2}$ & 0.733 & 0.864 & 0.825 \\
Adj $\mathbf{R}^{2}$ & 0.708 & 0.835 & 0.808 \\
F count & 29.29 & 30.598 & 50.298 \\
Chow Test (3,29) & - & 18.447 & - \\
Hausman Test (3) & - & - & 26.107 \\
\hline
\end{tabular}

Data source: data processing $\left({ }^{*}\right)$ significant at $\left.\alpha 1 \%,{ }^{* *}\right)$ significant at $\alpha 5 \%$

Discussion

\section{Interest rate}

The interest rate has a positive coefficient, meaning that the higher the interest rate will increase credit in the agricultural sub-sector. Therefore, interest rate does not have an effect on the credit position of the agricultural sub-sector. It is in accordance with the theory that interest rate has a negative effect on credit. In other words, if there is an increase in interest rates, it will reduce the amount of credit. However, the results of the estimation show the opposite which have a positive coefficient. If the interest rate increases by $1 \%$, the amount of credit also increases by Rp. 2814 billion. This finding is consistent with the study of Maiti et al. (2020) and Panimbing \& Sutrisno (2018) where interest rates do not have a negative effect on credit, and the Rai \& Purnawati (2017) study of interest rates also has a positive effect. However, it is not consistent with the study of Asrori, (2012), Kalesar et al. (2016), Maulana \& Iskandar (2018), Purba et al. (2016), and Rompas (2018) found that interest rates have a negative effect on credit.

These results indicate that interest rate has a positive coefficient, meaning that high interest rate actually has a tendency to encourage credit applications in the agricultural subsector. According to Rai \& Purnawati (2017), this indicates that the interest rate is not really a problem as though the interest rate is rising, applications for credit is still made to meet the needs. According to Hardana et al. (2019) a higher interest rate is considered remuneration and is a natural and not burdensome. 


\section{Number of Farmers in the Agriculture Sector}

The variable of the number of farmers in the agricultural sub-sector shows a positive influence on credit in the agricultural sub-sector. The increase in the number of farmers will increase the amount of credit in the agricultural sub-sector. The coefficient of the number of farmers is 0.005 , indicating that an increase in the number of farmers by 1 million farmers will increase credit by Rp. 5 million rupiah. This value is considered very low which supports the data from the Ministry of Agriculture (2019) that the proportion of credit in the agricultural sector is still low with only $9.7 \%$ of the total existing credit. Figure 1 shows the proportion of credit per economic sector, where the agricultural sector occupies the fourth position. These findings can show three things. First, farmers are chalenged by the difficulties in accessing credit from the financial institutions. According to Hardana et al. (2019), the main problem of access to credit that is faced by wrong farmers is complicated administrative procedures. In addition, another factor that causes difficulty in accessing credit is collateral. According to Marta \& Satria (2016), sufficient collateral is the basis to determine whether a credit application is accepted or not. Not all farmers are willingly to apply for credit or loan which leads to small numbers of the additional credit occurrence. Second, farmers have applied for credit but with a relatively small credit score. Third, farmers have applied for loans with a higher value, but the approval of the credit score is small because agriculture has a high risk, so financial institutions are reluctant to provide larger credit.

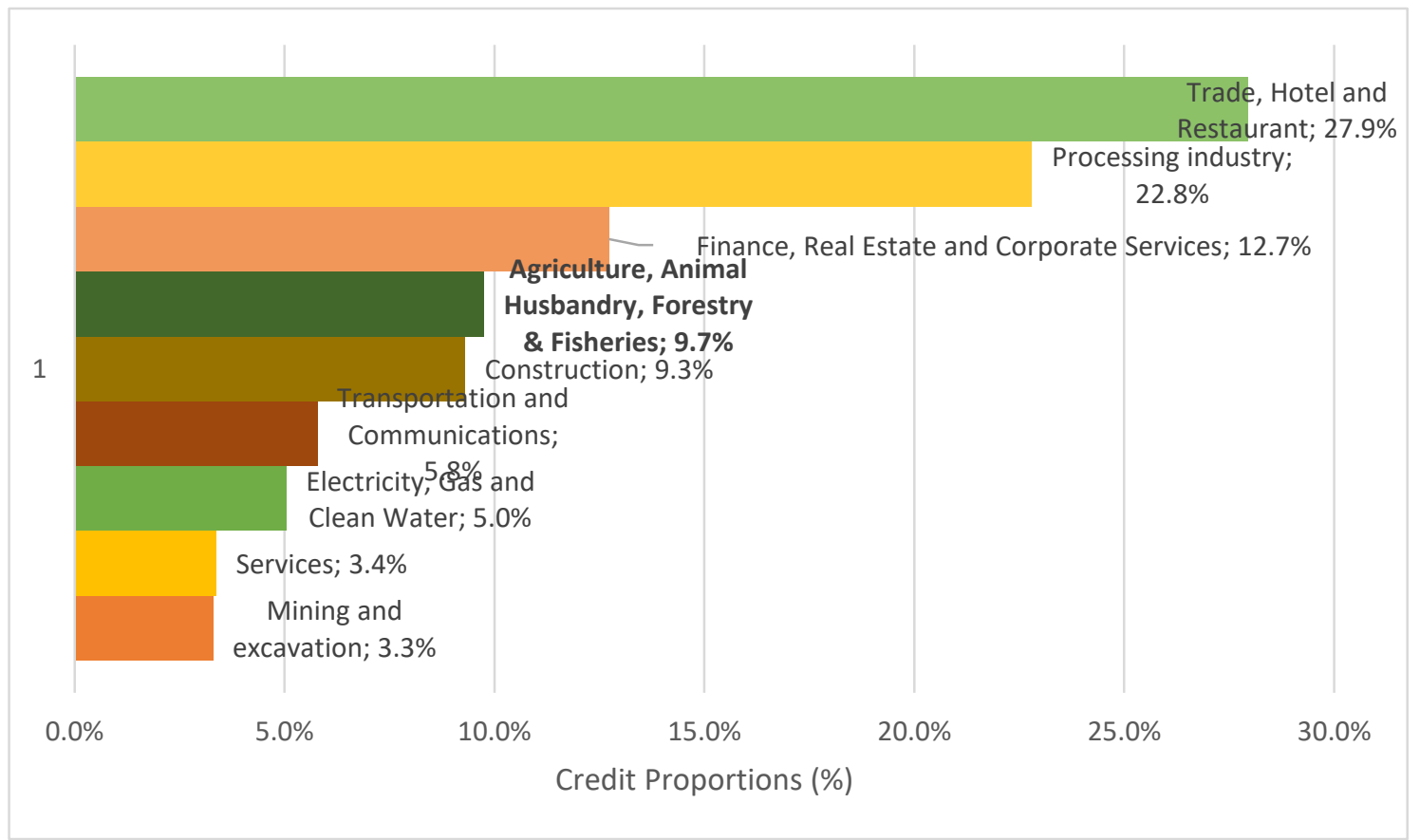

Source:The Ministry of Agriculture (2019)

Figure 1. Credit Proportion per Economic Sector in 2019 


\section{Agricultural Sub-Sector Gross Domestic Product}

The agricultural sub-sector gross domestic income variable has a positive effect on credit in the agricultural sub-sector. The GDP coefficient is 1.079, meaning that an increase in income from the agricultural sub-sector by Rp. 1 billion will increase the credit of Rp. 1.076 billion. This shows that the increased income in the agricultural sector will give farmers the ability to repay credits. Asante-Addo et al. (2017) states that farmers with higher incomes have rarely refused loan applications or their credit amounts are reduced. This finding is consistent with the study of Hardana et al. (2019), Kalayaan et al. (2016) and Aggarwal et al. (2014). The increase in gross national production in the agricultural subsector indicates an increase in capacity and condition of economy, which are the two criteria for credit.

Based on the estimation results above, it is partially identified that the income, in this case the Gross Domestic Product and the number of farmers in the agricultural sub-sector, has an effect on the amount of credit in the agricultural sub-sector. Considering the importance of credit that will be used for capital development of the agricultural sector, some efforts that can be done are to increase the Gross Domestic Product of the agricultural sector and to increase the capacity of farmers. Furthermore, it is necessary to increase farmers' access to financial institutions so that more farmers can access credit. According to Aggarwal et al (2014), to involve individuals in the mainstream financial system, and in order to provide many benefits, farmers need to have financial literacy. To increase financial literacy, it is necessary to provide financial education to farmers. J. M. Hogarth et al (2007) stated that the need for financial education will have an impact on making better decisions that will increase economic resilience and also achieve well-being. The existence of good financial education about financial benefits will increase farmer participation since AsanteAddo et al. (2017) stated that farmers participate in the credit program because they are aware of the benefits of accessing savings and loan services. The study of Hardana et al (2019) shows that horticultural farmers in East Java access credit is influenced by education. Likewise with the study of Aggarwal et al (2014), there is a positive relationship between the level of financial literacy and educational qualifications

For this reason, financial education is important, even Wafula (2017) stated that financial planning and investment activities, financial education should be linked to the curriculum in elementary schools so that individuals will get financial information earlier in life. The same thing was stated by Ashari (2009b), that educating the public to be more familiar with and able to access to financial institutions. 


\section{Conclusions And Suggestions}

Based on the estimation results, it can be concluded that the amount of credit in the agricultural sector is positively and significantly influenced by the number of farmers and Gross Domestic Product, while interest rates have a positive effect on the credit position of the agricultural sub-sector. To increase farmers' access to financial institutions, it is necessary to increase financial education so that it will increase financial literacy. Good financial literacy will have an impact on better decision making which will increase the economic resilience of farmers.

\section{Acknowledgment}

We thank the Institute for Research and Community Service (LPPM) of Ahmad Dahlan University for providing financial support and opportunities.

\section{REFERENCE}

Aggarwal, N., Gupta, M., \& Singh, S. (2014). Financial Literacy among Farmers: Empirical Evidence from Punjab. Pacific Business Review International, 6 (7), 36-42.

Asante-Addo, C., Mockshell, J., Zeller, M., Siddig, K., \& Egyir, I. S. (2017). Agricultural credit provision: what really determines farmers' participation and credit rationing? Agricultural Finance Review, 77 (2), 239-256. https://doi.org/10.1108/AFR-022016-0010

Ashari. (2009a). Optimization of the Agricultural Sector Program Credit Policy in Indonesia. Agricultural Policy Analysis Ashari., 7 (1), 21-42.

Ashari. (2009b). OPTIMIZATION OF AGRICULTURE SECTOR PROGRAM CREDIT POLICIES IN INDONESIA Policy Optimization of Credit Program for Agricultural Sector in Indonesia The experience of the monetary crisis in 1998 has made everyone aware that the agricultural sector has a role to play st. Agricultural Policy Analysis, 7, 21-42.

Asrori, N. F. (2012). Analysis of Factors Affecting Investment Credit Distribution (Empirical Study on State-Owned Banks) (Vol. 2010, Issue 0510230132).

Astuty, H. S. (2015). The 6C Principles (Character, Capacity, Capital, Condition of Economy, Collateral and Constraints) in Student Entrepreneurship. Journal of Economia, 11 (1), 56. https://doi.org/10.21831/economia.v11i1.7756

Cahyono, E. F., \& Mardianto, M. F. F. (2017). Dominant Factors in the Islamic Banking Inclusion Index in the Agricultural Sector in Indonesia, Sylva Alif Rusmita. 8, 55-79.

Darmawanto. (2008). Agricultural sector credit development. Diponegoro University Semarang. 
Hardana, A. E., Pratiwi, D. E., \& Ambayoen, M. A. (2019). Analysis of Factors Affecting the Decision of Horticultural Farmers in Accessing Microfinance in East Java. Proceedings of the National Seminar on Wetlands Environments, 4 (April), 38-44. https://snllb.ulm.ac.id/prosiding/index.php/snllb-lit/article/viewFile/156/157

Hogarth, J. M., Kolodinsky, J., \& Hilgert, M. A. (2007). Financial education and community economic development. Financing Low-Income Communities: Models, Obstacles, and Future Directions, 9781610444, 72-94.

Irfan, M. fadillah, Syapsan, \& Rosyetti. (2014). Analysis of the factors that influence consumption credit growth and its impact on economic growth in Indonesia. Jom FEKON, 1 (2), 1960-1970.

Ismail, A. (2018). Determinants of Umkm Credit Distribution at Commercial Banks in West Kalimantan Province. Proceedings of the 2018 SATIESP, 15-36.

Jannah, N. (2018). The Influence of Total Population and Gross Regional Domestic Product on Syari'ah Bank Financing in North Sumatra. At-Tawassuth, II (2), 224-244.

Kalesar, C. O., J. Kumaat, R., \& Mandeij, D. (2016). Analysis of Determinants of Demand for Investment Credit at Commercial Banks in North Sulawesi for the Period of 2008.12014.4. Periodic Journal of Scientific Efficiency, 16 (01), 831-838.

Ministry of Agriculture. (2019). Agricultural Sector Macro Indicator Statistics for Quarter IV (Vol. 01, Issue 01).

Maiti, M., Esson, I. A., \& Vuković, D. (2020). The impact of interest rate on the demand for credit in Ghana. Journal of Public Affairs, 20 (3). https://doi.org/10.1002/pa.2098

Marta, J., \& Satria, D. (2016). Collateral Effect to Bank Loan Probability for Microenterprises in West Sumatra. Indonesian Journal of Economics and Development, 16 (1), 1-14.

Maulana, H., \& Iskandar, E. (2018). Analysis of Integration of Agricultural Sector Financing and Farmer Exchange Rates in Indonesia. Journal of Regional Economics Unimal, 01 (3), 38-49.

Mewoh, R. L., Rotinsulu, T. O., \& Kawung, G. M. V. (2017). Analysis of Factors Affecting Lending Modla Kerha to Commercial Banks in North Sulawesi. Journal of Periodic Scientific Efficiency Studies, 4 (7), 103832.

Panimbing, B., \& Sutrisno, S. (2018). Determinants of Banking Credit Distribution A Case Study of Conventional Banks in Indonesia. JAD: Dewantara's Journal of Accounting \& Finance Research, 1 (2), 57-66. https://doi.org/10.26533/jad.v1i2.235 
Park, C.-Y., \& Mercado, R. J. (2015). Financial Inclusion, Poverty, and Income Inequality in Developing Asia. In SSRN Electronic Journal (Issue 426). https://doi.org/10.2139/ssrn.2558936

Purba, N. N., Syaukat, Y., \& Maulana, T. N. A. (2016). Factors Affecting The Level Of Credit Distribution In Conventional Bpr In Indonesia. Journal of Business and Management Applications, 2 (2), 105-117. https://doi.org/10.17358/jabm.2.2.105

Rai, I. A. A., \& Purnawati, N. K. (2017). Factors Affecting Credit at National Private Commercial Banks (Busn) Foreign Exchange. E-Journal of Management of Udayana University, 6 (11), 5941-5969.

http://www.ncbi.nlm.nih.gov/pubmed/17289255\%0Ahttp://dx.doi.org/10.1016/j. jclepro.2011.10.008\%0Ahttp://www.uwaba.or.tz/ National_Road_Safety_Policy_September_2009.pdf\%0Ahttp: //dx.doi.org/10.1016/j.resconrec.2011.03.010\%0Ahttp: //dx.doi.org/10.1016/j.pecs.20

Rompas, W. F. I. (2018). Analysis of the Effect of Interest Rates and Exchange Rates on Credit Demand in Banks in the City of Manado. Periodical Journal of Scientific Efficiency, 18 (02), 204-215.

Ummah, B. B., Nuryartono, N., \& Anggraeni, L. (2015). Analysis of Financial Inclusion and Income Equity in Indonesia. Journal of Economics and Policy 